\title{
Mineralocorticoid Receptor, Heat Shock Proteins and Immunophilins Par- ticipate in the Transmission of the Tubulogenic Signal of Aldosterone
}

\author{
Will W. Minuth*, ${ }^{,}$, Annette Blattmann ${ }^{1}$, Lucia Denk, ${ }^{1}$ and Hayo Castrop ${ }^{2}$ \\ ${ }^{I}$ Department of Molecular and Cellular Anatomy, University of Regensburg, Regensburg, Germany \\ ${ }^{2}$ Department of Physiology, University of Regensburg, Regensburg, Germany
}

\begin{abstract}
Aldosterone exhibits a tubulogenic activity on renal stem/progenitor cells. Little information is available about the signaling between the mineralocorticoid receptor (MR) and the proteins in the cytoplasm. To obtain information, renal stem/progenitor cells from neonatal rabbit were cultured at the interface of an artificial polyester interstitium in a perfusion container for 13 days. Development was registered with Soybean Agglutinin (SBA). Microscopy revealed that treatment with aldosterone $\left(1 \times 10^{-7} \mathrm{M}\right)$ resulted in numerous SBA-labeled tubules. Interference with mineralocorticoid receptor (MR) and heat shock protein (hsp) 90 using geldanamycin $\left(3,6 \times 10^{-6} \mathrm{M}\right)$ or radicicol $\left(1 \times 10^{-6} \mathrm{M}\right)$ showed a lack of tubule development. Disturbing MR and hsp 70 with quercetin $\left(2 \times 10^{-4} \mathrm{M}\right)$ and KNK $437\left(1 \times 10^{-4} \mathrm{M}\right)$ generated SBAlabeled cell cluster but not structured tubules. Interference with MR and immunophilins by cyclosporin A $\left(2 \times 10^{-6} \mathrm{M}\right)$ and rapamycin $\left(2,2 \times 10^{-9} \mathrm{M}\right)$ did not influence the generation of numerous SBA-labeled tubules. In contrast, administration of FK $506\left(2 \times 10^{-8} \mathrm{M}\right)$ resulted in a lack of tubule development. Thus, the signal for development of tubules induced by aldosterone is mediated by interaction of MR, hsp 90, hsp 70 and immunophilin FKBP 12.
\end{abstract}

Keywords: Aldosterone, mineralocorticoid receptor, kidney, stem/progenitor cells, tubules, perfusion culture, rabbit.

\section{INTRODUCTION}

Theoretical and practical considerations about the application of stem/progenitor cells in renal injury and repair are the subject of intense biomedical and clinical research [1-4]. The future success of this therapeutic strategy will depend on an adequate integration of stem cells in the diseased organ and on the capability to regenerate functional nephron segments within a patho-physiological environment [5-7]. However, a complicated organ such as the kidney comprising numerous different cell types and exhibiting a sophisticated three-dimensional structure makes it difficult to follow stem cell development during the process of regeneration [8-14].

To simulate the specific spatial environment within the kidney and to learn more about nephron regeneration sophisticated culture techniques are required. Previous investigations demonstrated that an optimal environment for the spatial development of tubules derived from renal stem/progenitor cells can be created at the interphase of an artificial interstitium made of polyester fleece [15-19]. To maintain controlled nutrition and provision with oxygen, perfusion culture was performed that allowed continuous provision with fresh chemically defined medium [20].

While performing these innovative culture experiments at the interphase of an artificial interstitium, it was discovered that aldosterone exhibits a tubulogenic effect on renal stem/progenitor cells [21]. The development of tubules was revealed to be dependent on hormone concentration and

*Address correspondence to this author at the Department of Molecular and Cellular Anatomy, University of Regensburg, University Street 31, D-93053 Regensburg, Germany; Tel: +49 941943 2876; Fax: +49 941943 2868; E-mail:will.minuth@vkl.uni-regensburg.de temporal application. Formation of tubules could be inhibited by spironolactone and canrenoate in a concentrationdependent manner. The tubulogenic effect of aldosterone could not be mimicked by other steroid hormones such as testosterone and estrogen or by molecular precursors of the synthesis pathway such as cholesterol, pregnenolone, progesterone, 11-desoxycorticosterone or corticosterone. Lack of tubule development after dexamethasone treatment demonstrated that the tubulogenic effect of aldosterone is related to the mineralocorticoid receptor (MR) and not to the glucocorticoid receptor (GR).

The intracellular processing of the tubulogenic signal evoked by aldosterone is unknown [22]. Earlier experiments demonstrated that MR is not randomly distributed within the cytoplasm of the target cell but stays in close molecular contact with hsp 90 and 70 [23]. Both proteins, in turn are in close proximity to immunophilins especially FKBP 12 [24]. To obtain insights into the intracellular processing of the activated MR and the related tubulogenic signal renal stem/progenitor cells were treated with aldosterone in combination with substances that disrupt the interaction between MR, hsp 90, hsp 70 and immunophilins. Thus, cultures were performed in the presence of geldanamycin, radicicol, quercetin, KNK 437, cyclosporine A, rapamycin and FK 506 respectively. Our data suggest that hsp 90, hsp 70 and immunophilin FKBP 12 are strongly involved in the tubulogenic effect of aldosterone.

\section{MATERIALS AND METHODS}

\section{Isolation of Embryonic Explants Containing Renal Stem/Progenitor Cells}

One day old New Zealand rabbits were anesthetized with ether and killed by cervical dislocation as described earlier 
[19]. Both kidneys were removed immediately. Each kidney was dissected into two parts. By stripping off the capsula fibrosa with fine forceps, a thin embryonic tissue layer containing numerous collecting duct ampullae, S-shaped bodies and nephrogenic mesenchyme was harvested. The isolated embryonic renal tissue was placed between two punched out layers of polyester fleece (Walraf, Grevenbroich, Germany) measuring $5 \mathrm{~mm}$ in diameter. This arrangement resulted in a sandwich-like configuration with the freshly isolated embryonic tissue in the center and two layers of polyester fleece covering the outer sides (Fig. 1a).

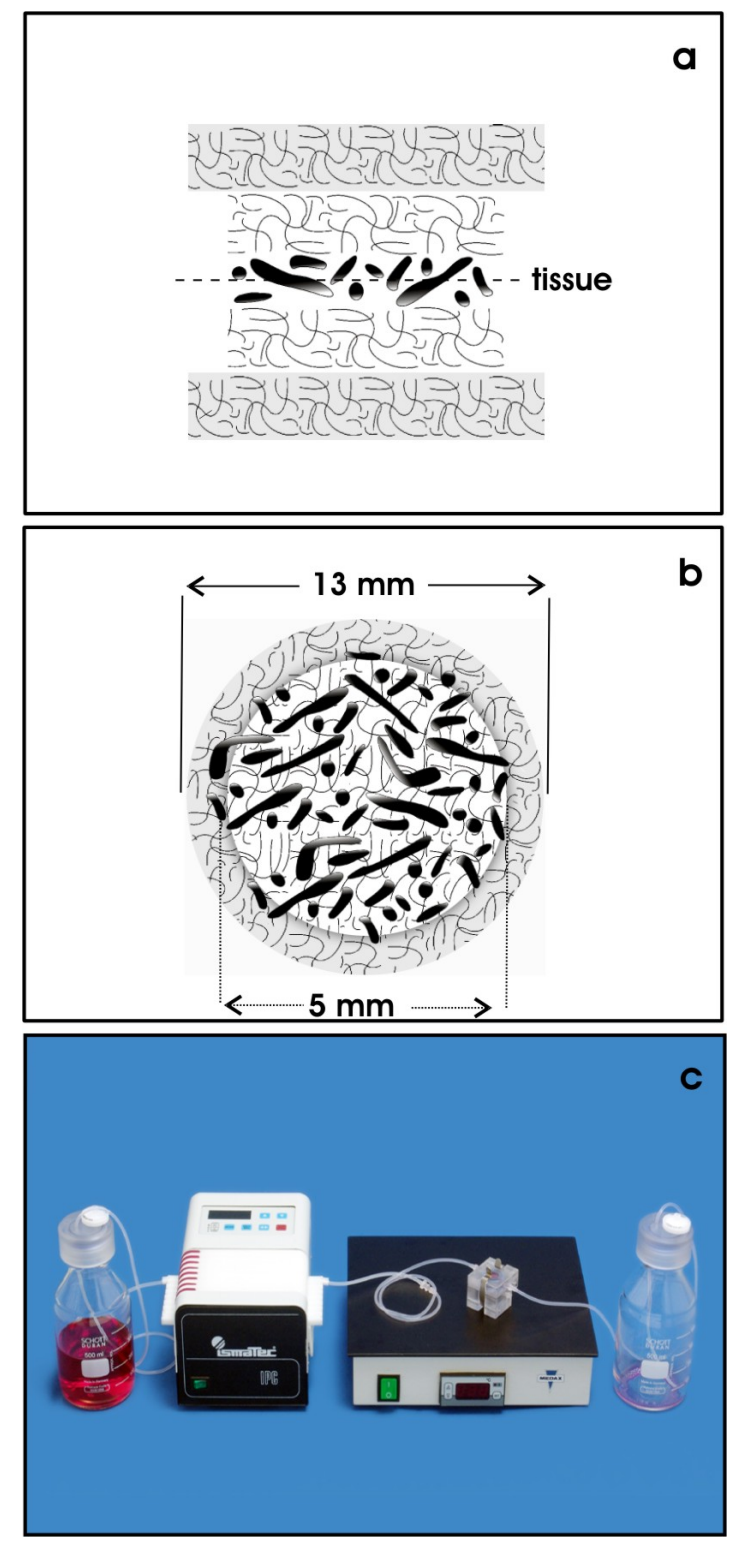

Fig. (1). Illustration of the culture set-up to generate renal tubules at the interphase of an artificial interstitium. Isolated embryonic renal tissue derived from the outer cortex of neonatal rabbit (a) was placed between two punched out layers of polyester fleece measuring $5 \mathrm{~mm}$ respectively $13 \mathrm{~mm}$ in diameter (b). This basic sandwich set-up was mounted in a Minusheet ${ }^{\circledR}$ holder. Then the assembly was used in a perfusion culture container with horizontal flow. Medium was continuously perfused for 13 days at a rate of $1 \mathrm{ml} / \mathrm{h}$ with an IPC N8 peristaltic pump (c). To maintain a constant temperature of $37^{\circ} \mathrm{C}$, the culture container was placed on a thermoplate and covered with a transparent lid.

\section{Sandwich Set-Up in a Perfusion Culture Container}

For further experiments, the basic sandwich set-up was held in a specific position during culture so that damage of the growing tissue was prevented. To this end, a base ring of a Minusheet ${ }^{\circledR}$ tissue holder with a $13 \mathrm{~mm}$ inner diameter was transferred to a perfusion culture container with horizontal flow characteristics (Minucells and Minutissue, Bad Abbach, Germany). A polyester fleece measuring $13 \mathrm{~mm}$ in diameter was mounted into the tissue holder. Then, the basic sandwich set-up containing renal stem/progenitor cells measuring $5 \mathrm{~mm}$ in diameter was inserted. Finally, a polyester fleece $13 \mathrm{~mm}$ in diameter was placed on top of the sandwich as a cover (Fig. 1a, b). After closing the lid of the perfusion culture container, the complete tissue-fleece construction was fixed in an exact position. The spatial area for tubule formation was $5 \mathrm{~mm}$ in diameter and up to $250 \mu \mathrm{m}$ in height. The specific interphase between the fleece layers produced an artificial interstitium providing an optimal microenvironment for the development of tubules during the entire culture period $[15,17,20]$.

\section{Perfusion Culture to Generate Renal Tubules}

Perfusion culture was performed as described earlier (Minuth et al. 2007a, Fig. 1c). Fresh medium was continuously perfused for 13 days at a rate of $1 \mathrm{ml} / \mathrm{h}$ with an IPC N8 peristaltic pump (Ismatec, Wertheim, Germany). To maintain a constant temperature of $37^{\circ} \mathrm{C}$, the culture container was placed on a thermoplate (Medax, Kiel, Germany) and covered with a transparent lid.

To generate renal tubules, chemically defined IMDM (Iscove's Modified Dulbecco's Medium including Phenolred, GIBCO/Invitrogen, Karlsruhe, Germany) was used. Up to $50 \mathrm{mmol} / 1 \mathrm{HEPES}$ (GIBCO) was added to the medium to maintain a constant $\mathrm{pH}$ of 7.4 under atmospheric air containing $0.3 \% \mathrm{CO}_{2}$. To evoke tubulogenic development, aldosterone $\left(1 \times 10^{-7} \mathrm{M}\right.$, Fluka, Taufkirchen, Germany) was present in the culture medium. To prevent infection an antibioticantimycotic cocktail $(1 \%$, GIBCO) was added to all culture media.

To interrupt the tubulogenic signal of aldosterone on the level of hsp 90, hsp 70 and immunophilins, the following substances were applied: geldanamycin $\left(3,6 \times 10^{-6} \mathrm{M}\right.$, Biomol, Hamburg, Germany) [25], radicicol (1 x 10-6 M, Sigma, Taufkirchen, Germany) [26], quercetin $\left(2 \times 10^{-4} \mathrm{M}\right.$, Biozol, Eching, Germany) [27], KNK 437 (1 x 10 $0^{-4} \mathrm{M}$, Calbiochem, Darmstadt, Germany) [28], cyclosporin A $\left(2 \times 10^{-6} \mathrm{M}\right.$, Fluka, Taufkirchen, Germany) [29], rapamycin $\left(2,2 \times 10^{-9} \mathrm{M}\right.$, Assay designs, Michigan, USA) [30] and FK $506\left(2 \times 10^{-8} \mathrm{M}\right.$, Sigma) [31]. Concentration range of substances were applied as seen in literature.

\section{Lectin-Labeling}

Developed tissues were analyzed on cryosections in longitudinal- or cross-sectioned view. Sections of $20 \mu \mathrm{m}$ thickness were fixed in ice-cold ethanol. After washing with phosphate buffered saline (PBS), the specimens were blocked with PBS containing 1\% bovine serum albumin (BSA) and 10\% horse serum for 30 minutes. For Soybean Agglutinin (SBA, Vector, Burlingame, USA)-labeling the samples were exposed to fluorescein-isothiocyanate (FITC)conjugated lectin diluted 1:2000 in blocking solution for 45 
minutes as described. Following several washes in PBS the sections were embedded with Slow Fade Light Antifade Kit (Molecular Probes, Eugene, USA) and then analyzed using an Axioskop 2 plus microscope (Zeiss, Oberkochen, Germany). Fluorescence images were taken with a digital camera at a standard exposure time of 1.3 seconds and thereafter processed with Corel DRAW 11 (Corel Corporation, Otawa, Canada).

\section{Scoring}

Tubular structures exhibited polarized cells, a visible lumen and a basal lamina. According to the profile of SBAlabeling, we used a specific score for evaluation of tubule development as described [19,21]. The presence of tubules, their number, length, intensity of labeling, lumen formation, and the existence of a basal lamina were registered. Each criterion was scored with one point resulting in a possible maximum of six points. Additional evaluation included whether these tubules occurred frequently or rarely and if cell clusters were present (Table 1).

\section{Amount of Cultured Constructs}

A total of 87 embryonic tissues were isolated and maintained in culture for the present study. All experiments were performed at least in triplicate. The data provided in the text are the mean of at least three independent experiments. All experiments are in accordance with the Animal Ethics Committee, University of Regensburg, Regensburg, Germany.

\section{RESULTS}

\section{Creation of an Artificial Interstitium}

After stripping off the capsula fibrosa from neonatal rabbit kidney, a thin tissue layer containing numerous stem/ progenitor cells was isolated and mounted in a specific holder. It was inserted in a perfusion culture container as described. A peristaltic pump constantly transported fresh medium into the perfusion container for a period of 13 days (Fig. 1c). The medium was not re-circulated, but collected in a waste bottle. Using this method, a constant provision of nutrition and oxygen could be obtained. Inside the perfusion container the isolated embryonic tissue was enclosed by layers of polyester fleece (Fig. 1a, b). A smaller fleece $5 \mathrm{~mm}$ in diameter was in direct contact with the tissue, while a larger one with $13 \mathrm{~mm}$ in diameter covered the sandwich configuration. Hence, the area for tissue development was $5 \mathrm{~mm}$ in diameter and up to $250 \mu \mathrm{m}$ in height. The interphase between the fleece layers produced an artificial interstitium, which was the biotechnical precondition for optimal development of tissue during a 13 day culture period. Using this experimental culture set-up we performed experiments to investigate the molecular environment of MR in the cytoplasm after aldosterone activation.

\section{Culture of Embryonic Renal Tissue in IMDM Lacking Aldosterone}

For controls, in the first set of experiments embryonic renal tissue was cultured for 13 days in chemically defined IMDM lacking aldosterone (Fig. 2a). Analysis of frozen tissue sections by fluorescence microscopy demonstrated that SBA-labeled cells or tubules could not be found in this series of experiments (Fig. 2b, c, Table 1).

\section{Development of Tubules in IMDM Containing Aldoster- one}

In the second series of experiments embryonic renal tissue was cultured in chemically defined IMDM containing aldosterone $\left(1 \times 10^{-7} \mathrm{M}\right.$, Fig. 3a). Fluorescence microscopy of frozen tissue sections cultured for 13 days revealed that numerous SBA-labeled tubules were found beside unlabeled tissue (Table 1). Most of the generated SBA-labeled tubules were detected in an oblique perspective (Fig. 3b), in which parts could better be observed in longitudinal view (Fig. 3c). The tubules exhibited a basal lamina, lining epithelial cells and a visible lumen.

These experiments clearly demonstrated that the generation of SBA-labeled tubules was dependent on the administration of aldosterone. However, data about the molecular environment of the activated MR were lacking. To elucidate steps in MR activation the following experiments were performed. We tested substances interacting with $\mathrm{MR}$ and

Table 1. Generation of tubules is interfered on the level of heat shock proteins and immunophilins. (IH) Iscove's medium plus Hepes, (A) aldosterone. Tubules were recognized exhibiting a lumen, lining epithelial cells and a basal lamina, while clusters were seen as an uncontrolled accumulation of cells $[15,19,21]$.

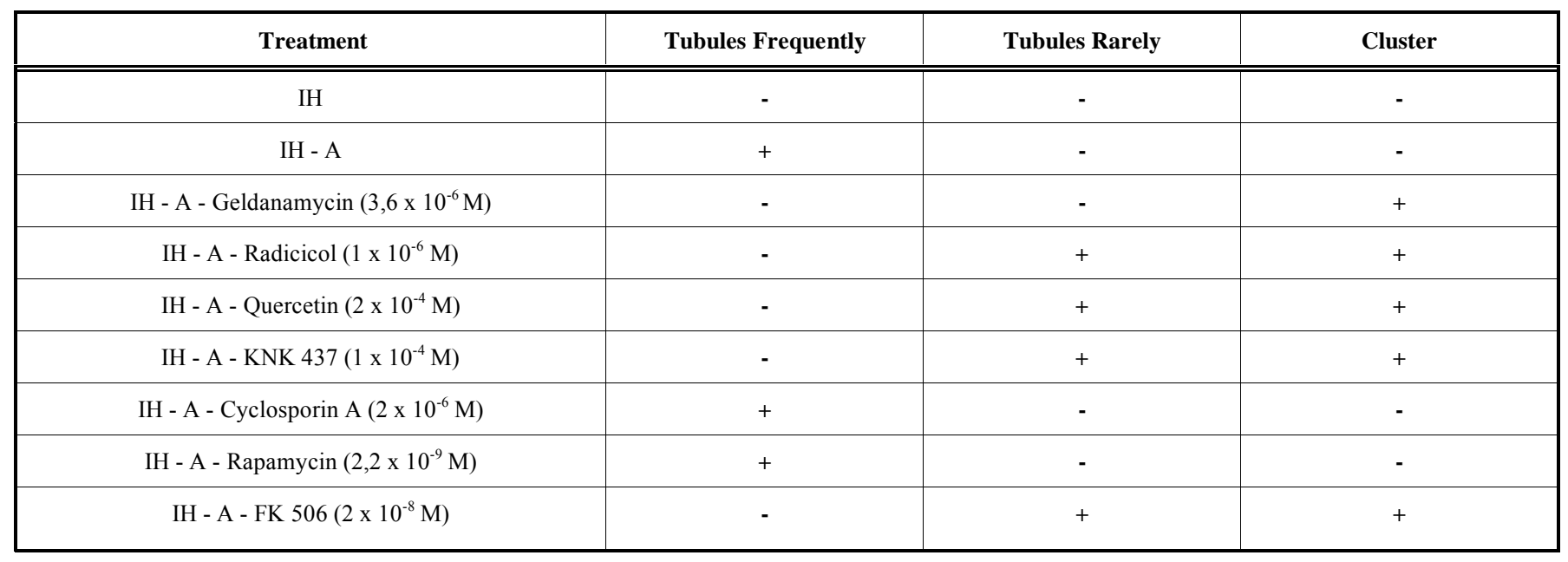




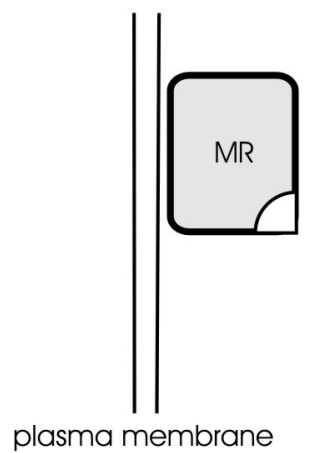

plasma membrane a

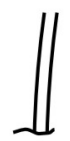

cytoplasm

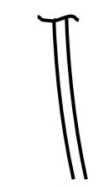

nucleus
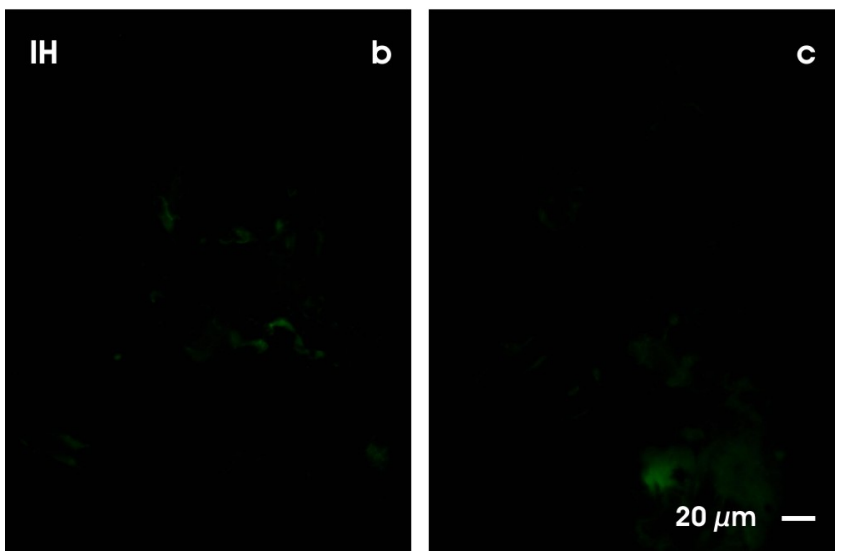

Fig. (2). Illustration of non-stimulated mineralocorticoid receptor in renal stem/progenitor cells (a) MR - mineralocorticoid receptor. Fluorescence microscopy on renal tissue generated in IMDM for 13 days without aldosterone administration (b, c). No SBA-label were detected in this series.

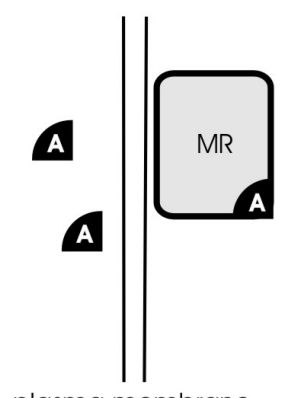

plasma membrane

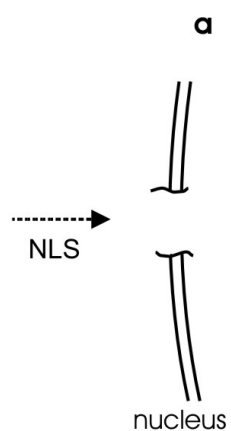

cytoplasm a

nucleus
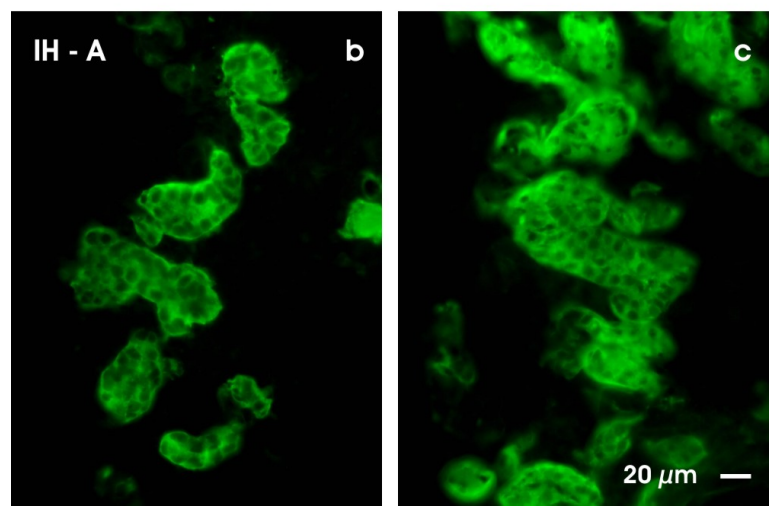

Fig. (3). Illustration of aldosterone-stimulated mineralocorticoid receptor (a) A - aldosterone, MR - activated mineralocorticoid receptor, NLS - nuclear localization signal. Fluorescence microscopy on renal tissue generated in IMDM for 13 days with aldosterone $\left(1 \mathrm{x} 10^{-7} \mathrm{M}\right)$ administration (b, c). Multiple SBA-labeled tubules can be seen. 


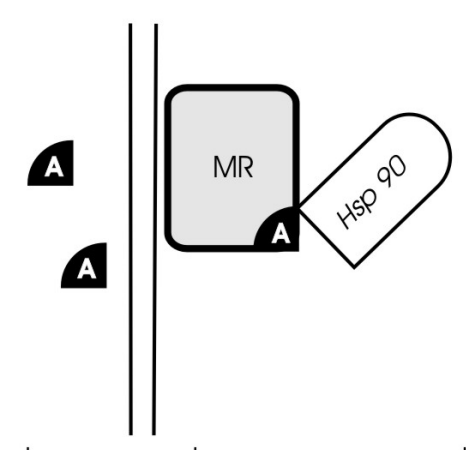

plasma membrane cytoplasm a

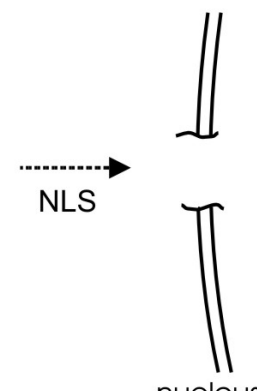

nucleus
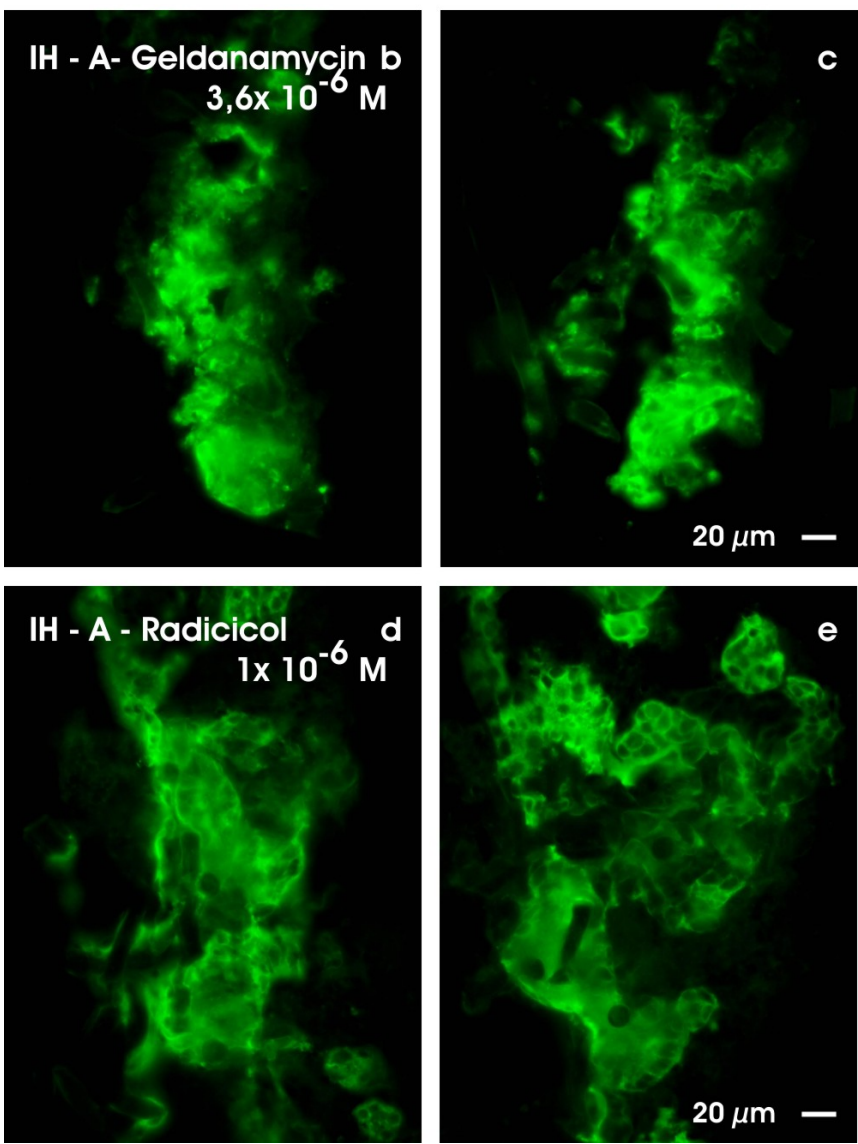

Fig. (4). Illustration of aldosterone-stimulated mineralocorticoid receptor in relation to hsp 90 (a) A - aldosterone, MR - activated mineralocorticoid receptor, NLS - nuclear localization signal. Fluorescence microscopy on renal tissue generated in IMDM for 13 days with aldosterone $\left(1 \times 10^{-7} \mathrm{M}\right)$ in combination with geldanamycin $\left(3,6 \times 10^{-6} \mathrm{M}, \mathbf{b}, \mathbf{c}\right)$ or radicicol $\left(1 \times 10^{-6} \mathrm{M}, \mathbf{d}, \mathbf{e}\right)$. Multiple SBA-labeled cells within cluster formation were found, while the application of radicicol resulted in a lack of tubules.

neighboring cytoplasmic proteins such as hsp 90, hsp 70 or immunophilins and registered reactions related to the tubulogenic signal.

Substances such as geldanamycin [25], radicicol [26], quercetin [27], KNK 437 [28], cyclosporine A, rapamycin or FK 506 which had been reported by other groups to interfere with MR were used [2, 19, 35]. In the present experiments we used these substances at the same or even higher concentrations than those previously reported. The culture period was 13 days. Classical toxic effects such as cell death or disintegration of tissue were not observed. However, we found interference of the applied substances with the structural development of SBA-labeled tubules generated in perfusion culture.

\section{Interfering the Contact Between MR and hsp 90}

In the third set of experiments embryonic renal tissue was cultured in IMDM containing geldanamycin $\left(3,6 \times 10^{-6} \mathrm{M}\right)$ in combination with aldosterone $\left(1 \times 10^{-7} \mathrm{M}\right)$ for 13 days (Fig. 4a). Geldanamycin specifically binds to hsp 90 thereby blocking the ATP binding site due to its higher affinity compared to ATP $[33,34]$. In this way, it disturbs the contact between hsp 90 and activated MR. The culture experiments 
revealed that structured tubules were not found in this series of experiments. Instead numerous SBA-labeled cells were localized in extended clusters (Fig. 4b, c, Table 1).

Radicicol is a macrocyclic antifungal substance that binds in the same way as geldanamycin [27]. It hinders ATPdependent conformational changes that are required for interactions with target proteins such as MR. Culture of embryonic tissue with radicicol $\left(1 \times 10^{-6} \mathrm{M}\right)$ in combination with aldosterone $\left(1 \times 10^{-7} \mathrm{M}\right)$ produced only a few structured tubules, but numerous SBA-labeled cells were detected in form of extended cluster formations (Fig. 4d, e, Table 1).
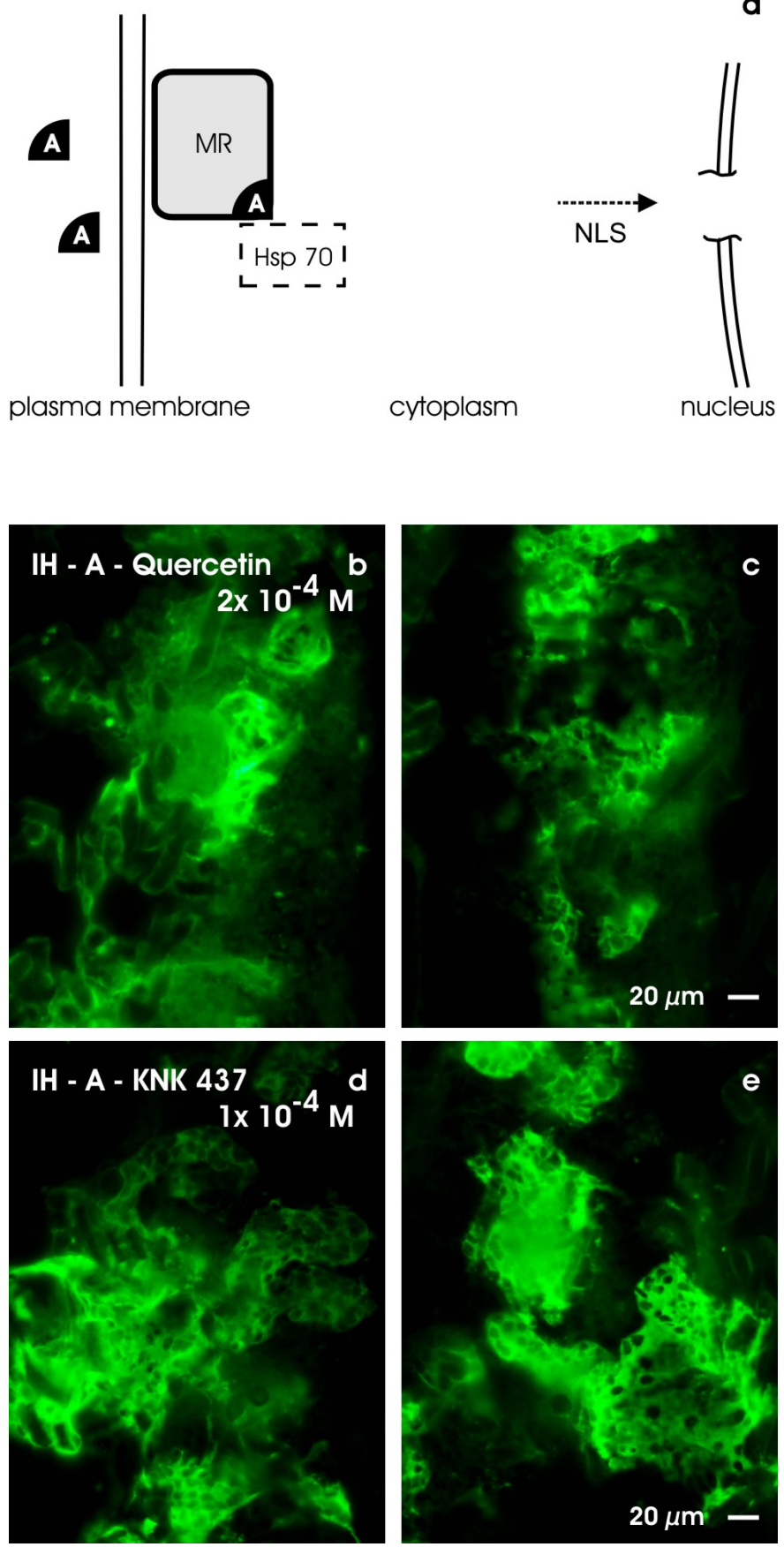

Fig. (5). Illustration of aldosterone-stimulated mineralocorticoid receptor in relation to hsp 70 (a) A - aldosterone, MR - activated mineralocorticoid receptor, NLS - nuclear localization signal. Fluorescence microscopy on renal tissue generated in IMDM for 13 days with aldosterone $\left(1 \times 10^{-7} \mathrm{M}\right)$ in combination with quercetin $\left(2 \times 10^{-4} \mathrm{M}, \mathbf{b}, \mathbf{c}\right)$ or KNK $437\left(1 \times 10^{-4} \mathrm{M}, \mathbf{d}\right.$, e). Multiple SBA-labeled cells within clusters were detected, only minor development of tubules is seen.

\section{Interference with the Contact of MR and hsp 70}

In the forth set of experiments substances such as quercetin and KNK 437 were tested. Both substances are known to interact with MR and the neighboring hsp 70 to interrupt the signaling initiated by aldosterone (Fig. 5a).

Quercetin is a flavonoid that inhibits hsp 70 expression by blocking heat shock factor 1 and thereby interferes indirectly with MR [19]. Culture experiments with quercetin $(2 \mathrm{x}$ $\left.10^{-4} \mathrm{M}\right)$ in combination with aldosterone $\left(1 \times 10^{-7} \mathrm{M}\right)$ showed that numerous SBA-labeled cells were found to be located 

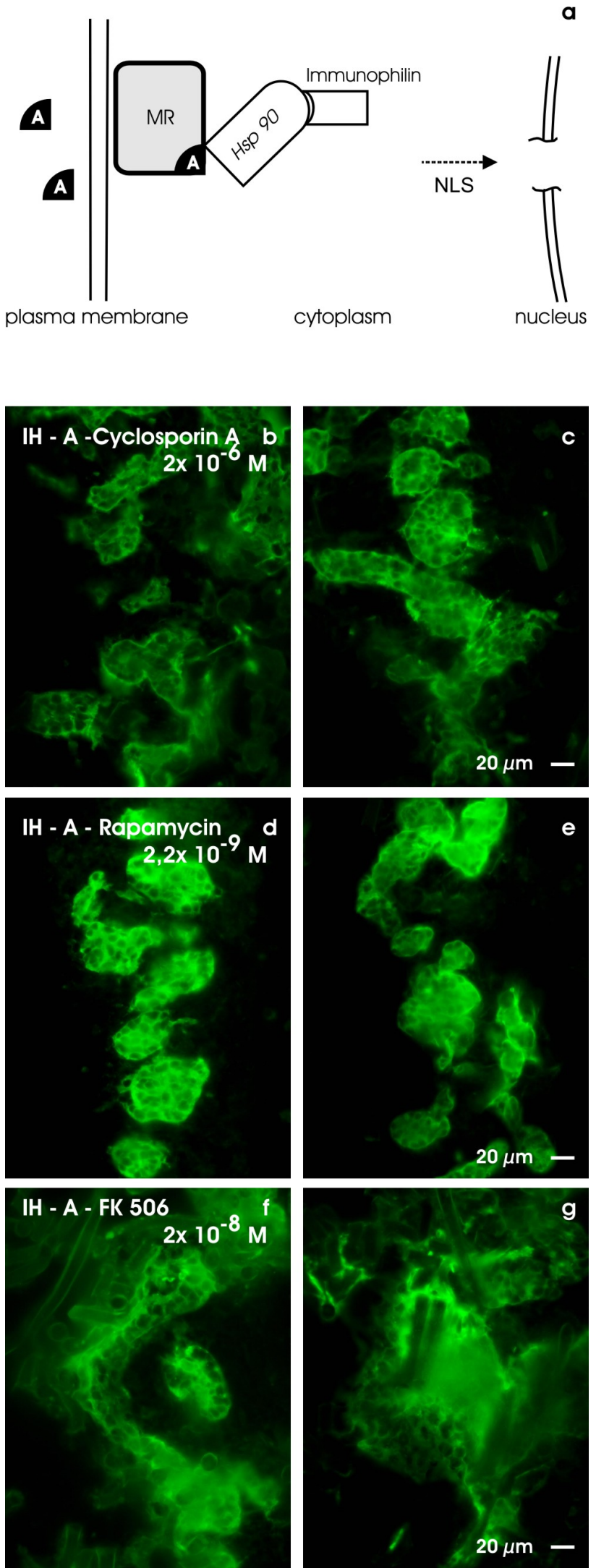

Fig. (6). Illustration of aldosterone-stimulated mineralocorticoid receptor in relation to hsp 90, hsp 70 and immunophilins (a) A - aldosterone, MR - activated mineralocorticoid receptor, NLS - nuclear localization signal. Fluorescence microscopy on renal tissue generated in IMDM for 13 days with aldosterone $\left(1 \times 10^{-7} \mathrm{M}\right)$ in combination with cyclosporin $\mathrm{A}\left(2 \times 10^{-6} \mathrm{M}, \mathbf{b}, \mathbf{c}\right)$, rapamycin $\left(2,2 \times 10^{-9} \mathrm{M}, \mathbf{d}, \mathbf{e}\right)$ and FK $506(2 \times$ $\left.10^{-8} \mathrm{M}, \mathbf{f}, \mathbf{g}\right)$. Multiple SBA-labeled cells were detected within extended cluster formations after application with FK 506 (f, g). Occasionally few and slightly labeled tubules were found. In contrast, numerous structured tubules were detected in series exposed to cyclosporin A (b, c) or rapamycin $(\mathbf{d}, \mathbf{e})$. 
within extended cluster formations (Fig. 5b, c). However, in some cases minor development of tubules and intensive cell cluster formation were observed (Table $\mathbf{1}$ ).

KNK 437 is a benzylidene lactam molecule that inhibits heat shock factor activity resulting in a decreased expression of heat shock proteins, thereby interfering indirectly with MR [32]. The culture experiments with KNK 437 (1 x $10^{-4}$ $\mathrm{M})$ in combination with aldosterone $\left(1 \times 10^{-7} \mathrm{M}\right)$ demonstrated that numerous SBA-labeled cells were found to be localized within extended cluster formations (Fig. 5d, e). In individual cases, few tubules with faint SBA-label were detected (Table 1).

\section{Interference Between MR and Immunophilins}

In the fifth set of experiments, we tested substances such as cyclosporin A, rapamycin and FK 506 interacting between MR and neighboring immunophilins (Fig. 6a, Table 1).

Cyclosporin A is an immunosuppressant drug, which binds to cyclophilin in close proximity to hsp 90 by forming a complex, which in turn inhibits calcineurin [36]. The culture experiments with cyclosporin A $\left(2 \times 10^{-6} \mathrm{M}\right)$ in combination with aldosterone $\left(1 \times 10^{-7} \mathrm{M}\right)$ demonstrated development of numerous structured SBA-labeled tubules (Fig. 6b, c). An inhibitory effect on tubule development was not observed (Table 1).

Rapamycin is also known as sirolimus. The substance is a macrolide antibiotic that binds to the cytosolic protein FK 506-binding protein 12 (FKBP 12) [36,37]. It belongs to the family of immunophilins that interact with hsp 90. Rapamycin forms a complex with FKBP 12 and thereby inhibits the mTOR pathway. The culture experiments with rapamycin $\left(2,2 \times 10^{-9} \mathrm{M}\right)$ in combination with aldosterone $\left(1 \times 10^{-7} \mathrm{M}\right)$ generated numerous SBA-labeled tubules (Fig. 6d, e). Inhibition of tubule development was not noticed (Table 1).

FK 506 is also called Tacrolimus. This macrolide is commonly used as an immunosuppressive drug. It binds to the immunophilin FKBP 12 by forming a complex, which interacts with hsp 90 [31]. Consequently, the protein phosphatase calcineurin is inhibited. The culture experiments with FK $506\left(2 \times 10^{-8} \mathrm{M}\right)$ in combination with aldosterone (1 x $\left.10^{-7} \mathrm{M}\right)$ demonstrated sparsely and only slightly stained tubules (Fig. 6f, $\mathbf{g}$ ). Multiple SBA-labeled cells were found to be localized to extended cluster formations (Table 1).

\section{DISCUSSION}

The present experiments were performed to elucidate steps in MR activation in response to the tubulogenic action of aldosterone. It is generally assumed that the activation starts when aldosterone reaches the target cell and penetrates the plasma membrane to reach MR in the cytoplasm. However, the mode of binding of aldosterone to MR and the ensuing cell biological interaction with cytoplasmic molecules are poorly understood [38].

It has been shown that in the absence of aldosterone, MR is in close contact with chaperones and immunophilins inside the cytoplasm. In closest contact to the ligand binding site of MR is hsp 90 [23,25,33,35]. The ATP-binding domain of hsp 90 faces the ligand binding site of MR. In close contact with MR are also heat shock protein 70 and immunophilins [39]. After binding of aldosterone to the MR these proteins are released, which in turn unmasks the nuclear localization signal (NLS) so that the activated MR can enter the nucleus [22].

In this system, it was unknown whether the mentioned chaperones and immunophilins are involved in the tubulogenic signal induced by aldosterone in renal stem/progenitor cells. To assess this issue, substances such as geldanamycin [25], radicicol [26], quercetin [27], KNK 437 [28], cyclosporin A [29], rapamycin [30] or FK 506 [31] were tested which interfere in the signaling between MR and hsp 90, hsp 70 and immunophilins.

Interference with the tubulogenic signal at the level of hsp 90 by geldanamycin $\left(3.6 \times 10^{-6} \mathrm{M}\right)$ in combination with aldosterone $\left(1 \times 10^{-7} \mathrm{M}\right)$ for 13 days, prevented the formation of structured tubules. Instead, numerous SBA-labeled cells were localized in extended clusters (Fig. 4b, c). Nearly the same results were obtained using radicicol $\left(1 \times 10^{-6} \mathrm{M}\right)$ in combination with aldosterone $\left(1 \times 10^{-7} \mathrm{M}\right)$. In this series we occasionally observed a few tubules. However, extended cluster formations were predominately found (Fig. $\mathbf{4 d}, \mathbf{e}$ ).

Disruption of the tubulogenic signal at the level of hsp 70 by quercetin $\left(2 \times 10^{-4} \mathrm{M}\right)$ in combination with aldosterone

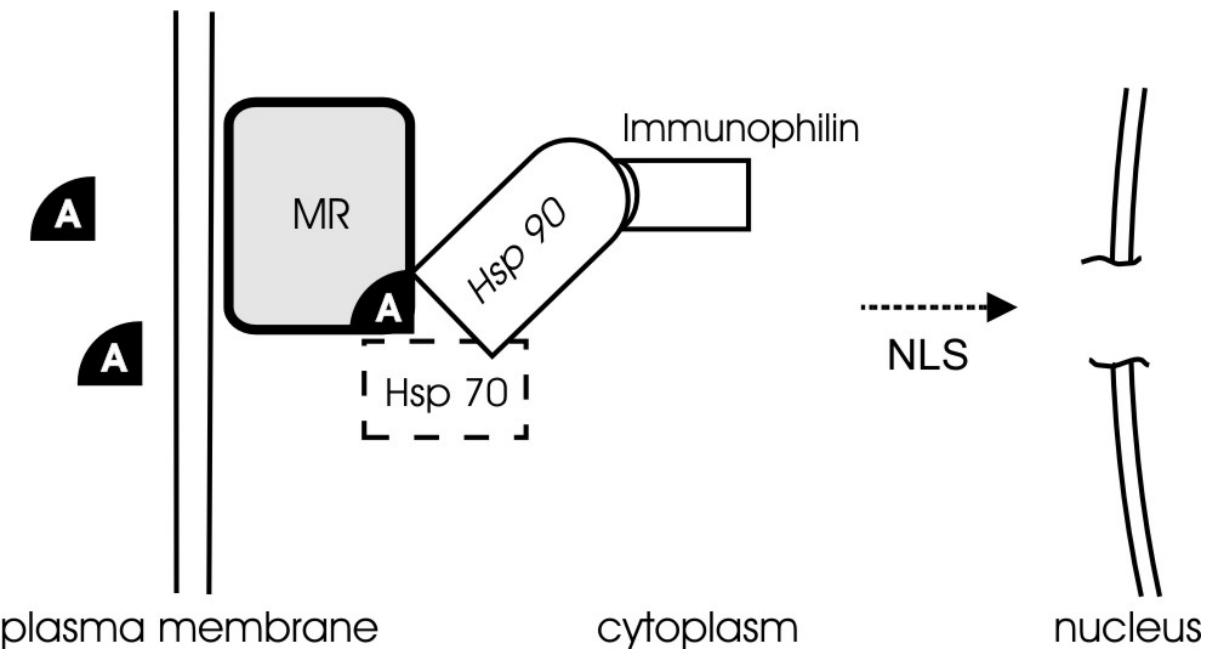

Fig. (7). Illustration of aldosterone-stimulated mineralocorticoid receptor in relation to hsp 90, hsp 70 and immunophilins (a) A - aldosterone, MR - activated mineralocorticoid receptor, NLS - nuclear localization signal. 

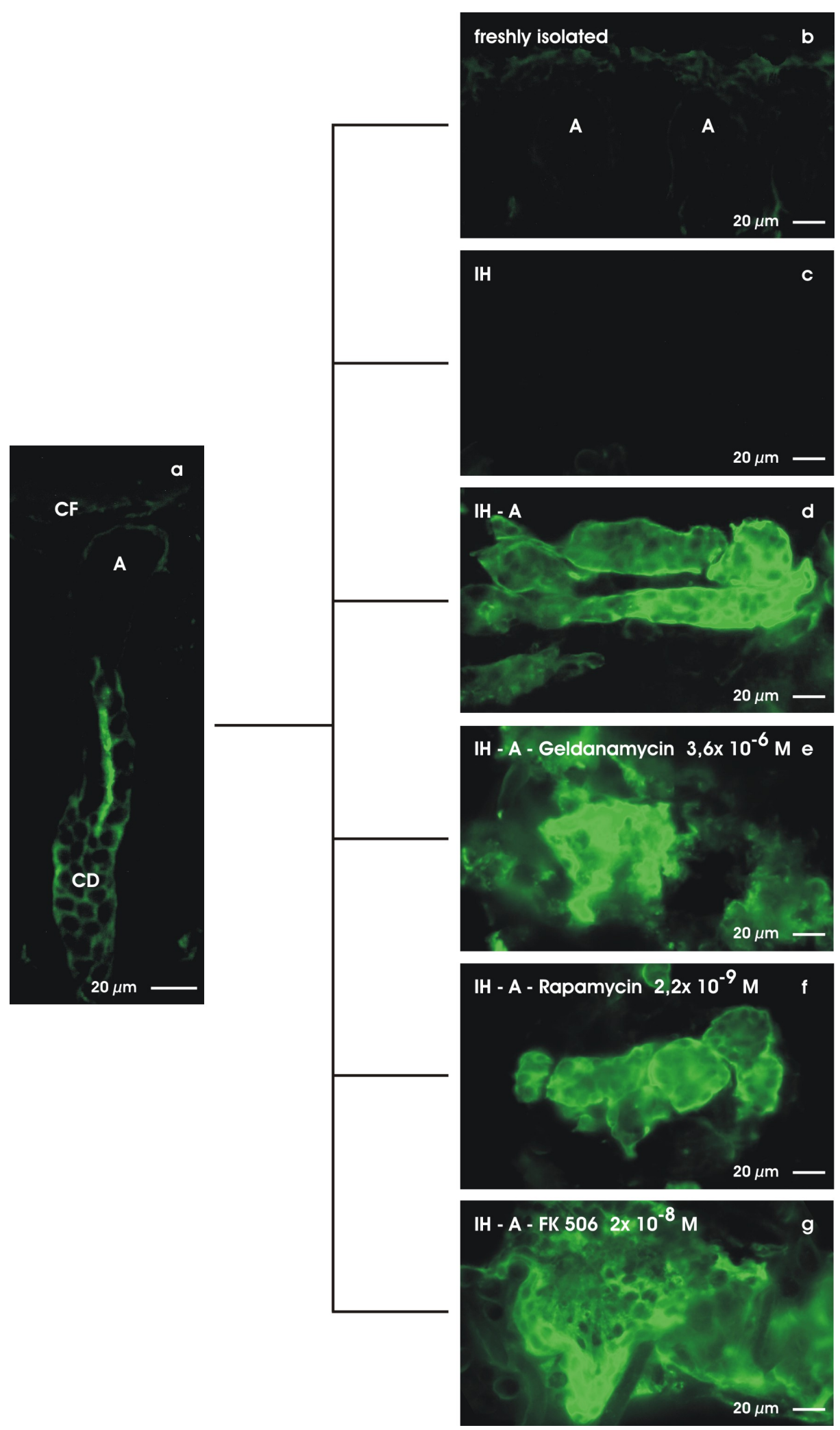

Fig. (8). Developmental pattern of SBA-labeled cells. The tip of the collecting duct ampulla (A) beyond the capsula fibrosa (CF) in the neonatal rabbit kidney is the site of renal epithelial stem/progenitor origin. It does not reveal cellular SBA-label in fluorescence microscopy. In contrast, the ampullar neck and further down the maturing collecting duct (CD) tubule shows intensive reaction (a). Freshly isolated embryonic tissue does not reveal SBA-label (b). Embryonic tissue without aldosterone application does not reveal SBA-label (c). Culture of tissue in the presence of aldosterone results in numerous SBA-labeled tubules containing a lumen and a basal lamina (d). Generation of tissue with aldosterone in combination with geldanamycin shows cell cluster (e). Culture of tissue with aldosterone in combination with rapamycin (f) demonstrates numerous tubules, while treatment with FK 506 shows clusters $(\mathrm{g})$. 
$\left(1 \times 10^{-7} \mathrm{M}\right)$ produced numerous SBA-labeled cells within extended cluster formations (Fig. 5b, c). However only minimal development of tubules could be detected. Similar results were obtained with KNK $437\left(1 \times 10^{-4} \mathrm{M}\right)$ in combination with aldosterone $\left(1 \times 10^{-7} \mathrm{M}\right)$. Numerous SBA-labeled cells were found to be localized within extended cluster formations, while only single tubules with faint SBA-label were detected (Fig. 5d, e).

Disturbance of the tubulogenic signal at the level of immunophilins revealed heterogeneous results. Culture experiments with cyclosporin $\mathrm{A}\left(2 \times 10^{-6} \mathrm{M}\right)$ in combination with aldosterone $\left(1 \times 10^{-7} \mathrm{M}\right)$ resulted in the development of numerous SBA-labeled tubules (Fig. $\mathbf{6 b}, \mathbf{c}$ ). Thus, an inhibitory effect on tubule development was not observed in this series of experiments. In addition, experiments with rapamycin $(2,2$ x $\left.10^{-9} \mathrm{M}\right)$ in combination with aldosterone $\left(1 \times 10^{-7} \mathrm{M}\right)$ led to the formation of numerous SBA-labeled tubules (Fig. $\mathbf{6 d}, \mathbf{e}$ ). In contrast, culture experiments with FK $506\left(2 \times 10^{-8} \mathrm{M}\right)$ in combination with aldosterone $\left(1 \times 10^{-7} \mathrm{M}\right)$ revealed multiple SBA-labeled cells localized in extended cluster formations (Fig. 6f, g), but only few and slightly stained tubules were found.

The present experiments demonstrated for the first time that activated MR displays a tubulogenic signal, which is disrupted by geldanamycin, radicicol, quercetin, KNK 437, and FK 506, but not by cyclosporin A and rapamycin. This result clearly indicates that the topological orientation of hsp 90, hsp 70 and immunophilin FKBP 12 is essential for the tubulogenic development induced by aldosterone (Fig. 7).

Earlier, it was shown that the application of aldosterone stimulates embryonic renal tissue so that only the epithelial stem cells develop further under described culture conditions. In the kidney cortex, this maturation process can be visualized by SBA-labeling (Fig. 8a).

Summing up, the tip of the collecting duct ampulla is known to be the site of origin of renal epithelial stem/progenitor cells and is found beyond the capsula fibrosa in the outer cortex of the neonatal rabbit kidney. The ampulla tip lacks SBA-labeling. In contrast, the ampulla neck and more mature collecting duct tubules (CD) in the deep cortex revealed intensive SBA-labeling. As demonstrated, a perfect developmental gradient between the embryonic ampulla tip and the maturing collecting duct can be shown.

This described development could be mimicked but also disrupted under the described culture conditions. After isolation, no SBA-labeling was detected in the embryonic tissue (Fig. 8b). Culture of the embryonic tissue for 13 days without aldosterone administration did not reveal any SBAlabeling (Fig. 2b, c, 8c). In contrast, application of aldosterone generated numerous SBA-labeled tubules (Fig. 3b, c, 8d). Culture of the embryonic tissue in medium containing geldanamycin and aldosterone revealed extended SBAlabeled cell clusters but no structured tubules (Fig. $\mathbf{4 b}, \mathbf{c}, \mathbf{8 e}$ ). However, interfering with immunophilins with cyclosporin A (Fig. 6b, c) or rapamycin (Fig. 6d, e, 8f) resulted in intensive tubule formation. In contrast, treatment with FK 506 resulted in a lack of tubule development (Fig. 6f, g, 8g), although this substance supposedly interferes with immunophilins. The reason for this discrepancy has to be elaborated.
Summarizing the results, we found that the tubulogenic signal of aldosterone is composed of two steps: (1) The development of SBA-labeled cells and (2) the formation of structured tubules. Both steps occur in parallel. However, since formation of tubules could be inhibited by geldanamycin, radicicol, quercetin, KNK 437, and FK 506, we suggest that MR in collaboration with hsp 90, hsp 70 and especially immunophilin FKBP 12, influences the development of tubules. Conversely, SBA labeling of cells is dependent on the activation of MR and can not further be influenced on the level of hsp 90, hsp 70 and immunophilins.

\section{ACKNOWLEDGEMENTS}

The technical assistance of Mr. A. Maurer is gratefully acknowledged.

\section{REFERENCES}

[1] Atala A. Tissue engineering, stem cells and cloning: current concepts and changing trends. Expert Opin Biol Ther 2005; 5: 879-2.

[2] Bussolati B, Camussi G. Stem cells in acute kidney injury. Contrib Nephrol 2007; 156: 250-58.

[3] Koh CJ, Atala A. Tissue engineering, stem cells and cloning: opportunities for regenerative medicine. J Am Soc Nephrol 2004; 15:1113-25.

[4] Little MH. Regrow or repair: potential regenerative therapies for the kidney. J Am Soc Nephrol 2006; 17: 2390-2401.

[5] Braam B, Verhaar MC, Blankestijn P, Boer WH, Joles JA. Technology insight: innovative options for end-stage renal disease from kidney refurbishment to artificial kidney. Nat Clin Pract Nephrol 2007; 3,10: 564-572.

[6] Hammerman MR. Treatment for end-stage renal desease: an organogenesis/tissue engineering odyssey. Transpl Immunol 2004; 12: 211-18.

[7] Kim SS, Park HJ, Han J, et al. Improvement of kidney failure with fetal kidney precursor cell transplantation. Transplantation 2007; 83:1249-1258.

[8] Hogan BLM, Kolodzief PA. Molecular mechanisms of tubulogenesis. Nat Rev 2002; 3: 513-23.

[9] Humphreys BD, Bonventre JV. The contribution of adult stem cells to renal repair. Nephrol Ther 2007; 3: 3-10.

[10] Mansilla E, Drago H, Sturla F, et al. Matrix superhighways configurations: new concepts for complex organ regeneration. Transplant Proc 2007; 39, 7: 2431 -33.

[11] Rookmaaker MB, Verhaar MC, van Zonneveld AJ, Rabelink TJ. Progenitor cells in the kidney: biology and therapeutic perspectives. Kidney Int 2004; 66:518-22.

[12] Steenhard BM, Isom KS, Cazcarro P, et al. Integration of embryonic stem cells in metanephric kidney organ culture. J Am Soc Nephrol 2005; 16:1623-31.

[13] McTaggert SJ, Atkinson K. Mesenchymal stem cells: immunobiology and therapeutic potential in kidney disease. Nephrology 2007; 12: 44-49.

[14] Vigneau C, Polgar K, Striker G, et al. Mouse embryonic stem cellderived embryoid bodies generate progenitors that integrate long term into renal proximal tubules in vivo. J Am Soc Nephrol 2007; 18:1709-20.

[15] Heber S, Denk L, Minuth W W. Modulating the development of renale tubules growing in serum-free culture medium at an artificial interstitium. Tissue Eng 2007; 13: 281-91.

[16] Minuth WW, Schumacher K. From the renal stem cell niche to functional tubule. Med Klin 2003; 98 (2): 31-35.

[17] Minuth WW, Sorokin L, Schumacher K. Generation of renal tubules at the interface of an artificial interstitium. Cell Physiol Biochem 2004; 14: 387-94.

[18] Minuth WW, Denk L, Heber S. Growth of embryonic renal parenchyma at the interphase of a polyester artificial interstitium. Biomaterials 2005; 26: 6588- 98.

[19] Minuth WW, Denk L, Hu K, Castrop H, Gomez-Sanchez C. Tubulogenic effect of aldosterone is attributed to intact binding and intracellular response of the mineralocorticoid receptor. CEJB 2007; 3: 307-25. 
[20] Hu K, Denk L, de Vries U, Minuth WW. Chemically defined medium environment for the development of renal stem cells into tubules. Biotechnol J 2007; 2: 992-95.

[21] Minuth WW, Denk L, Hu K. The role of polyester interstitium and aldosterone during structural development of renal tubules in serum-free medium. Biomaterials 2007; 28: 4418-28.

[22] Walther RF, Atlas E, Carrigan A, et al. A serine/threonine-rich motif is one of three nuclear localization signals that determine unidirectional transport of the mineralocorticoid receptor to the nucleus. J Biol Chem 2005; 280:17549-61.

[23] Pratt WB, Galigniana MD, Harrell JM, DeFranco DB. Role of hsp90 and the hsp90-binding immunophilins in the signaling protein movement. Cell Signal 2004; 16: 857-72.

[24] Cox MB, Riggs DL, Hessling M, Schuhmacher F, Buchner J, Smith DF. FK506-binding protein 52 phosophorylation: a potential mechanism for regulating steroid hormone receptor activity. Mol Endocrinol 2007; 21: 2956-67.

[25] Bamberger CM, Wald M, Bamberger A, Schulte HM. Inhibition of mineralocorticoid and glucocorticoid receptor function by the heat shock protein 90-binding agent geldanamycin. Mol Cell Endocrinol 1997; 131: 233-40.

[26] Batulan Z, Taylor DM, Aarons RJ, et al. Induction of multiple heat shock proteins and neuroprotection in a primary culture model of familial amyotrophic lateral sclerosis. Neurobiol Dis 2006; 24 : 213-25.

[27] Dokladny K, Wharton W, Lobb R, Ma TY, Moseley PL. Induction of physiological thermotolerance in MDCK monolayers: contribution of heat shock protein 70. Cell Stress Chaperones 2006; 11: 268-75.

[28] Koike T, Uno S, Ishizawa M, et al. The heat shock protein inhibitor KNK437 induces neurite outgrowth in PC12 cells. Neurosci Lett 2006; 410: 212-17.

[29] Sliwa M, Markovic D, Gabrusiewicz K, et al. The invasion promoting effect of microglia on glioblastoma cells in inhibited by cyclosporin A. Brain 2007; 130: 476-89.
[30] Tomiya T, Yamaoka Y, Nishikawa T, et al. Effect of rapamycin on hepatocyte function and proliferation induced by growth factors. Chemotherapy 2007; 53: 59-69.

[31] Rokaw MD, West ME, Palevsky PM, Johnson JP. FK-506 and rapamycin but not cyclosporin inhbit aldosterone-stimulated sodium transport in A6 cells. Am J Physiol 1996; 271:194-202.

[32] Manwell L A, Heikkila JJ. Examination of KNK437-and quercetinmediated inhibition of heat shock protein gene expression in Xenopus laevis cultured cells. Comp Biochem Physiol A Mol Integr Phys 2007; 148(3): 521-30.

[33] Onuoha SC, Mukund SR, Coulstock ET, Sengerova B, McLaughlin SH, Jackson SE. Mechanistic studies on Hsp90 inhibition by ansamycin derivatives. J Mol Biol 2007; 372: 287-97

[34] Xiao L, Lu X, Ruden DM. Effectiveness of hsp90 inhibitors as anti-cancer drugs. Mini Rev Med Chem 2006; 6:1137-43.

[35] Phillips JJ, Yao ZP, Zhang W, et al. Conformational dynamics of the molecular chaperone Hsp90 in complexes with a co-chaperone and anticancer drugs. J Mol Biol 2007; 537:1189-1203.

[36] Sanchez-Tillo E, Wojciechowska M, Comalada M, Farrera C, Lloberas J, Celada A. Cyclophilin A is required for M-CSFdependent macrophage proliferation. Eur J Immunol 2006; 36: 2515-24.

[37] Han HJ, Sigurdson WJ, Nickerson PA, Taub M. Both mitogen activated proteinkinase and the mammalian target of rapamycin modulate the development of functional renal proximal tubules in matrigel. J Cell Sci 2004; 117:1821-33.

[38] Lubarsky B, Krasnow MA. Tube morphogenesis: Making and shaping biological tubes. Cell 2003; 112: 19-24.

[39] Pratt WB, Toft DO. Steroid receptor interactions with heat shock protein and immunophilin chaperones. Endocr Rev 1997; 18,3: 306-60.

(C) Minuth et al.; Licensee Bentham Open.

This is an open access article distributed under the terms of the Creative Commons Attribution License (http://creativecommons.org/licenses/by/2.5/), which permits unrestrictive use, distribution, and reproduction in any medium, provided the original work is properly cited. 